Keywords: "developing" ethnicity, family photo albums, biographical photo interview, visual narrative, denotata and connotata of visual message, iconic codes

НАТСАК Органа Доржуевна - кандидат философских наук, ученый секретарь Тувинского института гуманитарных и прикладных социально-экономических исследований при Правительстве Республики Тыва (667000, Россия, Республика Тыва, г. Кызыл, ул. Кочетова, 4; nod695596@gтаil. com)

\title{
ОСОБЕННОСТИ ПОЛИТИЧЕСКОЙ СОЦИАЛИЗАЦИИ ЖЕНЩИН В ТУВИНСКОЙ НАРОДНОЙ РЕСПУБЛИКЕ (1921-1944 гг.)
}

Аннотация. В статье представлены результаты анализа опубликованных и архивных документов Коминтерна и Тувинской народно-революционной партии, идеологической литературы периода Тувинской Народной Республики для выявления особенностей политической социализации тувинских женщин. Автор исследует политическое влияние Коминтерна на ТНР, место женского вопроса во внутриполитической повестке ТНР а также, идеологию и формы работы с женщинами.

Ключевые слова: Тувинская Народная Республика, тувинские женщины, политическая социализация, общественно-политическая активность женщин, органы власти

\section{Введение}

В 2021 г. исполняется 100 лет с момента провозглашения Тувинской Народной Республики (далее - ТНР) как самостоятельного государства. В 1921 г. была принята первая Конституция ТНР, которая всем гражданам предоставила равноправие перед законом. Впервые в истории Тувы женщины получили политические права, возможность участвовать в общественно-политической жизни и через выборы быть представленными в органах власти.

В Конституции ТНР 1941 г. была осуществлена детализация прав женщин: женщине предоставлялись равные с мужчиной права в государственной, хозяйственной, культурной и общественно-политической жизни, а воспрепятствование их участию в указанных сферах жизни общества и государства, равно и поступлению женщин в школы, а также насильственная выдача замуж несовершеннолетних и вступление с ними в брак карались законом ${ }^{1}$.

По опыту Советской России в Туве были созданы все правовые условия для политической социализации. Однако законотворческий процесс опережал фактическую готовность тувинских женщин к активной общественной и политической жизни. В силу сложившихся культурно-исторических особенностей Тувы до 1921 г. тувинские женщины, несмотря на достаточно высокий статус в семье, не имели доступа к образованию и к государственным делам, которыми занимались исключительно мужчины. В связи с получением Тувой нового общественно-политического статуса самостоятельного государства перед правительством ТНР встала задача не только обучить грамоте тувинских женщин, но и объяснить им суть происшедших политических изменений,

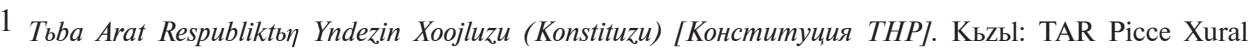
Prezidiumu. 1941. С. 30 (на тув. яз.). 
смысл законов и новых социальных норм и в последующем создать предпосылки для привлечения женщин в государственные и партийные структуры. В решении этих сложных задач большую роль сыграла международная организация «Коммунистический интернационал» (далее - Коминтерн).

\section{Влияние Коминтерна на решение женского вопроса в ТНР}

Историю политической социализации тувинских женщин, а также политическую историю ТНР нельзя рассматривать в отрыве от деятельности III Коммунистического интернационала и его влияния на события в ТНР, а также специфики понимания женского вопроса в мировой пролетарской революции. Полагаем, что только так можно понять логику событий, которые происходили, и решения, которые принимались.

Высший орган Коминтерна - конгресс избирал состав постоянно действующего исполнительного комитета (далее - ИККИ), который вел непосредственную работу с территориальными подразделениями, странами и уполномоченными лицами.

В Туве, как и в Монголии, также находились представители Коминтерна, которые вели идеологическую, политическую и тактическую координацию действий Тувинской народно-революционной партии и Монгольской народно-революционной партии (далее - МНРП). Представителей ИККИ в ТНР старались назначать с учетом знания монгольского языка, т.к. до введения в 1931 г. тувинской национальной письменности официальным письменным языком в ТНР выступал монгольский язык, однако не всегда. Следует отметить, что представители Коминтерна И. Райтер, М. Амагаев, работавшие в Монголии, делились опытом решения политических вопросов в этой стране с представителями организации в ТНР [Сердобов 1985: 6]. Они, к примеру, принимали непосредственное участие в подготовке VIII съезда ТНРП (1929 г.) в Туве, который стал переломным с точки зрения изменения политического курса с так называемой правой ориентации на левую, дальнейшего обострения антирелигиозной, антиламской, антифеодальной борьбы, разворота партии к женскому вопросу.

Практически все важные политические решения, тактика и технологии работы подсказывались ИККИ в виде готовых решений. Был налажен регулярный информационный обмен. «Включенное наблюдение» на месте осуществляли представители Коминтерна.

Акцент на женском вопросе в политике ТНРП и руководства ТНР был инспирирован политикой Коминтерна и его пониманием мировой пролетарской революции, в которой определенная роль отводилась женщинам.

V Конгресс Коминтерна в 1924 г. конкретизировал цели, задачи, формы и методы работы, которые были несколькими годами позже реализованы в ТНР. В этой концепции женщины представляли собой массу, за влияние на которую нужно бороться с контрреволюционерами. Работа среди женщин была названа «не побочной задачей коммунистических партий, а решающей частью основной задачи победы пролетариата». Приоритетными были названы задачи по освобождению женщин от бытовых и религиозных предрассудков через использование особых методов ${ }^{1}$. Коминтерн ставил задачу включения женщин во все организации: партии, профсоюзы, кооперативы, во все формы активной борьбы, включая даже военную самооборону, а также создания спе-

${ }^{1}$ Коммунистический Интернационал в документах: решения, тезисы, воззвания конгрессов Коминтерна и пленумов ИККИ 1919-1932 (под ред. Б. Куна). М.: Институт МарксаЭнгельса-Ленина при ЦК ВКП(б). 1933. С. 450-452. 
циальных органов при партии по всей вертикали, начиная от ЦК, для работы с женщинами.

Не случайно на первом организационном всетувинском собрании женщин в 1930 г. было вынесено решение о взаимодействии женотдела при ЦК ТНРП с женотделом Восточного секретариата ИККИ, регулярном направлении туда информации о проводимой работе с тувинскими женщинами и представителя тувинских женщин для прохождения инструктажа. Было внесено предложение взять на вооружение советский опыт работы с женщинами и адаптировать этот опыт к положению в Туве ${ }^{1}$. На этом же собрании было принято решение изучать опыт работы с женщинами в соседнем монгольском государстве, народ которого, как и тувинцы, вели кочевой образ жизни.

В ходе информационного обмена с ИККИ в 1930 г. женотдел ЦК ТНРП докладывал в ИККИ, что среди учащихся общеобразовательных школ и слушателей партийной школы появились первые девушки, что аратки выдвигаются на руководящие должности: три из них выбраны членами ЦК партии, одна - членом ЦКК, 15 выдвинуты на партийно-государственную работу в хошунах. На обсуждение был вынесен проект нового закона о семье и браке. В 1932 г. в ИККИ сообщали о женорганизаторах и делегатских собраниях в ТНР, о росте числа партийных женщин и членов ТРСМ [Сердобов 1985: 164].

Как показывают партийные документы, женский вопрос стал одним из часто обсуждаемых на съездах ТНРП и пленумах ЦК ТНРП вплоть до момента присоединения ТНР к СССР в 1944 г. Полагаем, что активное обсуждение женского вопроса в повестках съездов ТНРП и иных партийных собраний, конкретная постановка задач и принятие решений были связаны с рекомендациями Коминтерна.

\section{Социализация женщин в политической повестке ТНР (1921-1944 гг.)}

Анализ документов позволил автору сформулировать условно три этапа развития данного вопроса.

1. 1921-1929 г., подготовительный этап. Созданы формальные правовые условия для политического, экономического, гражданского равноправия женщин. Однако в силу традиционных устоев общества, необходимости решения первоочередных государственных вопросов, массовой безграмотности женщин процесс реальной социализации женщин шел достаточно медленно, призывы к активному вовлечению женщин в партийные, общественные структуры, органы власти оставались во многом на уровне деклараций.

2. 1929-1941 гг. - активный этап. VIII съезд ТНРП в 1929 г. стал ключевым в активизации работы с женщинами, вслед за съездом прошло первое всетувинское организационное собрание женщин. В 1930 г. тувинское государство приняло национальную письменность, которая ускорила ликвидацию безграмотности женщин. Женщин стало больше в партии и Тувинском революционном союзе молодежи (далее - ТРСМ); на выборах 1930 г. женщины вошли в местные органы власти. В этот период принимались все возможные меры по подготовке специалистов из числа женщин, включая отправление на учебу за границу.

3. 1941-1944 гг. - мобилизационный этап. Экономика ТНР переходит на мобилизационный режим в связи с Великой Отечественной войной в СССР. От женщин требуется не только быть политически активными, но и способ-

${ }^{1}$ Bükü Tiva- yin emegteichüd - ün jokiyan baigulugchi nar ba idebkitei kišigüd- un ang adugar hural-un tobchi togtagal [Постановление Первого всетувинского организационного собрания женшин]. Кызыл. 1930. С. 12-13 (на монг. яз.). 
ными заменить мужчин в хозяйстве и экономике, если это потребуется, быть готовыми к обороне страны.

Необходимо отметить, что вплоть до вхождения Тувы в состав СССР во всех партийных документах женский вопрос, вне зависимости от количественной динамики, рассматривался в духе критики и самокритики.

Впервые вопрос о включении тувинских женщин в партийные ряды и активизации женщин на местах был поднят в 1924 г. после того, как в ЦК ТНРП констатировали, что женщины мало представлены в партии. В том же году было принято постановление о направлении в районы Тувы членов партии для организации работы с женщинами и создания групп активисток ${ }^{1}$.

На VI съезде ТНРП (1927 г.) было отмечено, что работа по привлечению женщин в партию не была проведена должным образом. В этой связи было решено разъяснять женщинам задачи партии, работу с женщинами поручить новому составу ЦК, а также активно продвигать и готовить тувинских женщин к работе в партии и в государственном управлении ${ }^{2}$.

VII съезд ТНРП (1928 г.) указал на отсутствие размаха и слабое разворачивание культурно-просветительской, воспитательной работы среди населения, особенно среди женщин-араток, недостаточность числа женщин в партийных и общественных структурах, в ревсомоле [Очерки истории... 1975: 65]. На этом съезде было принято решение создать специальный орган по работе с женщинами. В 1928 г. при ЦК ТНРП был организован отдел по работе с женщинами. Вслед за этим была выстроена административная сеть по работе с женщинами, которая охватывала всю Туву, для ведения «низовой политики». Внедрены формы самоорганизации женщин (женсоветы, женские комитеты, делегатские группы).

Ha VIII съезде ТНРП (1929 г.) С. Тока ${ }^{3}$ выступил с большим докладом по вопросам образования и культуры, затронув и женский вопрос. Он подчеркнул отсталость Тувы в части образования и культуры, отсутствие собственной письменности. По его словам, монгольскую письменность в тувинском государстве знали только 1,5\% населения, при этом практически нет женщин, которые знают грамоту 4 . Такое положение он объяснял не только колониальным прошлым страны, когда «Тува много столетий находилась под гнетом Китая, Монголии, затем царской России, эксплуататорским интересам которых невыгодно было развитие в Туве экономики, образования, культуры», но и бездействием правых в руководстве тувинского государства. На съезде было раскритиковано отсутствие политических и практических мероприятий со стороны предыдущего руководства партии по «раскрепощению» тувинских женщин. В организационные задачи ТНРП по итогам съезда были включены такие меры, как вовлечение женщин в работу в государственных, кооперативных и других органах, запрет купли и продажи женщин через применение судебно-репрессивных мер, борьба с семейным и бытовым закрепощением ${ }^{5}$.

1 Национальный архив Республики Тыва (НА РТ). Ф. 1. Оп. 2. Д. 36. Л. 3-4.

2 Tiva arad-un hubisraltu nam-un tobchi tohtagal [Постановление VI съезда ТНРП]. Кызыл. 1927. С. 6 (на монг. яз.).

3 Салчак Тока (1901-1973) - тувинский, советский государственный деятель, выпускник Коммунистического университета трудящихся Востока (КУТВ) - учебного заведения Коминтерна. С 1929 г. был вторым секретарем ЦК ТНРП, министром культуры ТНР. С 1932 до 1944 г. руководил ТНРП. В советский период с 1944 по 1973 г. возглавлял областной комитет партии (ВКП(б), КПСС).

4 Tiva arad-un hubisraltu nam-un naymadurar yeke hural- un tobči togtaral [Постановление VIII съезда ТНРП]. Кызыл. 1929. С. 35-44 (на монг. яз.).

5 Там же. С. 17. 
Одним из главных итогов съезда стали меры по ускорению разработки и внедрения тувинской письменности. Если посмотреть справку о знании грамоты среди делегатов VIII съезда, то из 148 делегатов 100 были неграмотными, 20 человек слабо умели писать и читать по-монгольски, на среднем уровне 18 человек, и только 10 хорошо знали монгольскую письменность. Из 148 человек читать и писать на русском языке могли 7 человек ${ }^{1}$.

После VIII съезда была принята обновленная программа ТНРП, в которую включили обязательное обучение всех девушек младше 18 лет (замужних, незамужних), включая не только грамоту и культуру, но и знания о политике и положении в государстве. Фактически это стало началом системной политической социализации тувинских женщин.

K IX съезду ТНРП в 1932 г. Тува уже 2 года как имела собственную национальную письменность, показатели грамотности населения достигли 30\%. В Туву вернулась первая волна национальных кадров, подготовленных за границей, преимущественно в СССР. Во внутренней политике в достаточно острой фазе была антифеодальная, антиламская борьба: было конфисковано имущество этих классов, подавлено вооруженное восстание на Хемчике в 1930 г. Прошли чистки в партии и первая волна политических репрессий. Традиционная тибетская медицина оказалась под запретом, шаманизм был объявлен реакционным. В итоге старый фундамент, на котором строилось тувинское общество, был разрушен. Все это привело к тому, что внутренний и внешний политический фон к моменту проведения IX съезда был крайне напряженным.

В стране шел серьезный раскол внутри тувинского общества. Часть политического и экономического класса - бывшие феодалы, духовенство, собственники зажиточных хозяйств - были названы «агентами империализма»; съезд призвал «бдительно наблюдать за ними». Военное вторжение Японии в Маньчжурию в 1931 г. повлияло на мобилизацию и военизацию в тувинском обществе. В этой ситуации требовалось еще большая работа среди женщин. Этим, на наш взгляд, был вызван призыв на IX съезде к «скорейшему поголовному охвату грамотностью рабочих и батраков и усилению работы по ликбезу среди женщин-араток» ${ }^{2}$. Женщины представляли стратегически важную часть населения, за которую идейно и идеологически нужно было бороться: «Слабая работа среди трудящихся женщин создает почву для агитации, враждебной аратской диктатуре» ${ }^{3}$.

В 1936 г. С. Тока сформулировал задачи ТНРП в связи с VII Конгрессом Коминтерна. По оценке Тока, тувинские женщины все еще не раскрыли свой потенциал и отстают по уровню своего развития от мужчин: «Политические знания женщин на низком уровне, они до сих пор робеют перед мужчинами, если говорить по старым правилам, “arnь cazblbaan”, то есть “лица еще не раскрылись”. По этой причине и партия, и правительство по-особому относятся к женщинам, им делаются разные послабления» ${ }^{2}$ С. Тока критически высказался по поводу результативности работы ТНРП, профсоюзов, ревсомола в женском вопросе: показатели грамотности женщин отставали от таковых мужского населения, женщин количественно было меньше среди обучающихся, число служащих-женщин на 15 декабря 1935 г. было всего 71 чел., и именно по этому показателю судили об уровне политической грамотности женщин.

1 VIII съезд ТАРП в резолюциях. (20 октября - 10 ноября 1929 г.). Тувинская Аратская Республика. Кызыл-Хото. 1930. С. 147.

2 Резолюции IX съезда ТАРП (20 февраля - 10 марта 1932). Кызыл. 1932. С. 22-23.

3 Там же. С. 29.

4 Toka. KOMINTERNANbD VII Tugaar kongrezi polgas TARN sorulgalarb /Тока. VII Конгресс Коминтерна и задачи ТНРП]. Кызыл: Комитет по печати. С. 91 (на тув. яз.). 
Новым явилось то, что, помимо стандартного набора целей по женскому вопросу, С. Тока обратился к членам партии - мужчинам с призывом подавать личный пример в продвижении своих женщин и отказаться от дискриминационного отношения к женщине в семейных отношениях. «Члены партии должны бороться на самом деле с уничижительным отношением к женщине, которая находится рядом... членам партии нужно, прежде всего, подавать личный пример, приобщать к культуре, образованию и политическим знаниям своих отсталых подруг-женщин» 1 .

К 1938 г., к 17-летию тувинского государства, были изданы тезисы о достижениях за этот период, где отмечалось, что политическая активность женщин ТНР растет и они готовы защищать свои революционные права ${ }^{2}$.

К XII съезду ТНРП (1940 г.) женщины составляли 25,9\% общего числа членов ТНРП (всего 6053 членов партии, женщин - 1 572), на партийных курсах прошли обучение за 1939-1941 гг. 246 человек: 208 мужчин и 38 женщин (15\%). Возросло число грамотных женщин: к 1940 г. 86,5\% женщин освоили грамоту. 892 женщины работали по линии партии, ревсомола и в правительстве ТНР 3 . Следует отметить, что в 1940 г. Х.А. Анчимаа-Тока 4 была избрана на высокую государственную должность ТНР - Председателя Президиума Малого Хурала ТНР, став первой в мире женщиной - главой государства.

Несмотря на положительные сдвиги, работа с женщинами все еще оценивалась как недостаточная и слабая. На VII пленуме ЦК ТНРП в 1944 г. С. Тока «назвал истинным равноправием» то, что тысячи тувинских женщин на равных с мужчинами работают в народном хозяйстве и участвуют в общественной жизни 5 . Новеллой в его риторике по женскому вопросу явился акцент на экономике: «Главная цель работы женских активов, женских организаторов, партийных и ревсомольских организаций в кожуунах, сумонах, арбанах добиться увеличения в разы количества женщин, работающих в промышленности, сельском хозяйстве, на транспорте и так в каждой отрасли, чтобы женщины смогли, если нужно, как советские женщины, сменить мужчин во всех отраслях. Этого требует сегодняшняя ситуация» 6 . С. Тока потребовал от партийных организаций хуралов дойти до каждой юрты, донести политическую информацию до каждой аратки, до каждой крестьянки, до каждой работницы, добиться большего охвата женщин во всех отраслях народного хозяйства, культурном строительстве, в политической жизни страны, общества. Такая постановка задачи была беспрецедентной. Безусловно, такой подход был продиктован военным временем: юридически ТНР находилась в состоянии войны с фашистской Германией. 14 июня 1941 г. Политбюро ЦК НТРП принимает решение о перестройке работы на военный лад ${ }^{7}$.

1 Там же. C. 93.

2 TAR 17 cbl ojunga ARN TK - nьп yndurgen tezizi [Тезисы, изданные ЦК ТНРП к 17-летию THР]. Кызыл: культурно-массовый отдел ЦК ТНРП. 1938. С. 44 (на тув. яз.).

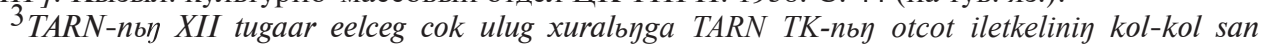
kergyzygleri [Основные цифры отчетного доклада ЦК ТНРП на внеочередном ХІІ Великом Хурале ТНР]. Кызыл: ЦК ТНРП. 1941 (на тув. яз.).

4 Хертек Анчимаа-Тока (1912-2008) - тувинский, советский государственный деятель, выпускница КУТВ. С 1938 г. заведовала отделом по работе с женщинами при ЦК ТНРП, в 1940-1944 гг. была Председателем Президиума Малого Хурала ТНР, с 1945 по 1961 гг. - заместителем председателя Тувинского облисполкома, в 1962-1979 гг. - заместителем председателя Совета министров Тувинской АССР.

5 TARN Tөp Komitedinin 7 tugaar plenuти [VII пленум ЦК ТНРП]. Кызыл: ЦК ТНРП. 1944. С. 55 (на тув. яз.).

6 Там же. С. 56.

7 РГАСПИ. Ф. 495. ОП. 153. Д. 76. Л. 25-27. 
Было принято отдельное постановление ЦК ТНРП о задачах трудящихся женщин в Отечественной войне советского народа от 18 сентября 1941 г. ${ }^{1}$ Была организована работа женщин для пошива одежды, подарков для Советской армии, организована сдача скота, шерсти. Главными в этом постановлении были четыре задачи: мобилизация женщин для оказания помощи Советской армии, политико-воспитательная работа среди женщин и разъяснение значения войны, военная подготовка женщин и обучение женщин мужским профессиям (шофер, тракторист и т.д.), в т.ч. охоте на пушного зверя и технике рыболовства ${ }^{2}$. Первый массовый женский митинг в ТНР прошел в Кызыле в 1942 г., в нем участвовали более 800 чел. В хошунных центрах были по этому примеру организованы митинги советских и тувинских женщин ${ }^{3}$.

Таким образом, к 1944 г. женщины ТНР прошли путь интенсивных социально-политических, экономических трансформаций, в силу обстоятельств военного времени начали осваивать мужскую работу и мужские профессии.

\section{Женский вопрос в контексте партийных и аппаратных чисток}

Политические чистки в рядах ТНРП начались в июле-сентябре 1929 г., по времени совпав со второй волной чисток в СССР. Вычищение ТНРП привело к существенному сокращению членского состава: число партийцев сократилось с 2278 чел. до 1 188, или на 48\%. За партийной чисткой последовала чистка государственного аппарата, в ходе которой, преимущественно по социальноклассовому признаку, убрали бывших феодалов [Очерки истории... 1975: 76]. Следующим этапом стала чистка на хошунном и сумонном уровнях.

Необходимо отметить, что при проведении политических чисток среди членов ТНРП в 1929 г. рекомендовалось к женщинам-членам партии применять особый - патерналистский - подход. В инструкции по проведению партийной чистки указывалось: «При проверке женщин - членов партии, нужно составить список. Если они не знают партийные задачи, не проявляют активного участия, спрос будет с соответствующей ячейки, хошунного комитета партии или с более образованных членов партии, так как они могли не проводить просветительской работы среди них... Члены комиссии должны хорошо поговорить с ними. Если в будущем будут активны, можно оставить в партии» 4.

Для рассматриваемого женского вопроса данные явления важны, т.к. чистки и классовая борьба в ТНР фактически дали расширение возможностей для женщин интегрироваться в управленческие органы и электоральные процессы. Кто-то должен был занять места ушедших. Через год после начала партийной чистки (1930 г.) прошли выборы в хошунные и сумонные хуралы, по результатам которых политическая представленность женщин выросла. Это было как результатом целенаправленной политики по продвижению женщин, так и открывшимися возможностями для женщин после партийной чистки.

Социальное, общественно-политическое продвижение получали прежде всего женщины с бедняцко-середняцким происхождением, не связанные кровно и идейно с политическими оппонентами руководства ТНРП. С этой точки зрения слово «женщина» не просто ассоциировалось с гендерной принадлежностью, оно приобретало политическое значение.

1 РГАСПИ. Ф. 495. ОП. 153. Д. 76. Л. 99-101.

2 Там же.

3 Там же. Л. 61, 169.

4 Tiva arad-un hubishaltu nam-un kešigüd-i šilraqu ba ceberlekü tuhai dziraburi [Инструкция о чистке членов ТНРП]. Кызыл. 1929. С. 8-10 (на монг. яз.). 


\section{Заключение}

Мировой опыт повышения представленности женщин в органах власти систематизирован и сгруппирован в несколько подходов: гендерно-нейтральный подход, политика «позитивной дискриминации», партийное квотирование, гендерное нормирование, квотирование мест в парламентах, политическая разнарядка и система поддерживающих действий (affirmative actions) [Гендерная реконструкция... 2004: 19-20]. В Тувинской Народной Республике политический протекционизм в отношении женщин исходил от партии и государства. Опыт ТНР в вопросах политической социализации и участия женщин с учетом стартовых социокультурных условий, кочевой специфики жизни является достаточно уникальным как по интенсивности и результативности за короткий промежуток времени, так и своему характеру. Этот путь не попадает полностью ни в одну из вышеуказанных групп. Система поддерживающих действий частично может охарактеризовать особенности политической социализации тувинских женщин и их продвижения в органы власти и управления в XX в. Но в большей степени это был целенаправленный государственный патернализм в отношении женщин.

Конституции ТНР предоставили тувинским женщинам политические права, гражданские свободы, конституционно закрепленное равноправие с мужчинами, доступ к управлению государством, образованию, современному здравоохранению. Тувинским женщинам не пришлось бороться за свои права. Несмотря на правовые основания, женщины не сразу были готовы к практическому использованию своих прав. Сложившаяся в тувинском обществе политическая культура, социальные нормы, система ценностей, самоидентификация женщины, круг интересов которой ограничивался продолжением рода, воспитанием детей, ведением хозяйства, не позволяли ей автоматически перейти в новое общество. Вместе с тем женщины для новой власти представляли политически важную часть общества, которую нужно было просвещать, вовлекать в классовую и антирелигиозную борьбу, экономику и производство. Для этого нужна была почти что насильственная эмансипация женщин сверху.

Главной структурой, определявшей внутреннюю и внешнюю политику ТНР, в т.ч. и в женском вопросе, был Коминтерн в лице Восточного секретариата и женотдела ИККИ. Коминтерн был «мозговым центром» для выработки и последующего тиражирования технологий и методов работы с учетом специфики страны. В методах и формах работы с женщинами в ТНР практически не было своих собственных практик. «Красные юрты», «кочевые школы», «красные уголки», делегатские собрания, сеть женотделов и активисток - все эти формы работы были рекомендованы Коминтерном и реализованы не только в ТНР, но и в других странах, например в Монголии.

В социализации тувинских женщин была своя эволюция, начиная от лозунгов: «вырвать из темноты и невежества» до «в случае необходимости женщины должны заменить мужчин по примеру советских женщин». И это всего за два десятилетия. В условиях потенциальной угрозы со стороны Японии для МНР и ТНР, начала Великой Отечественной войны в СССР тувинские женщины должны были стать готовыми к обороне страны и ведению хозяйства, работе на производстве без мужчин в случае необходимости. Все это требовало ускоренной эмансипации женщин.

В условиях немногочисленности населения ТНР политические чистки, репрессии, поражение в политических (лишение избирательных прав) и экономических (конфискация имущества) правах бывших феодалов, лам образовали пустоты в политическом поле (партия, ревсомол, органы управления), которые нужно было заполнять женщинами и беднотой. Таким образом, эти 
процессы способствовали активному проникновению женщин в общественнополитические структуры и во власть, а также их вертикальной мобильности.

Важно отметить, что продвижение женщин по линии партийных, государственных и общественных структур имело классовый характер. Важным критерием приоритетности продвижения было социальное происхождение и политическая надежность.

\title{
Список литературы
}

Гендерная реконструкция политических систем: сборник статей. 2004. СПб: Алетейя. 991 с.

Очерки истории Тувинской организации КПСС. 1975. Кызыл: Тувинское книжное издательство. $405 \mathrm{c}$.

Сердобов Н. А. 1985. Коминтерн и революционная Тува. Кызыл: Тувинское книжное издательство. 238 с.

NATSAK Organa Dorjuevna, Cand.Sci. (Philos.), Academic Secretary of the Tuvan Institute of Humanities and Applied Social and Economic Research under the Government of the Republic of Tuva (4 Kochetova, Kyzyl, Russia, 667000; nod695596@gmail.com)

\section{FEATURES OF POLITICAL SOCIALIZATION OF TUVAN WOMEN: HISTORICAL COMMENTS AND MODERN TRENDS (1921-1944)}

\begin{abstract}
The article presents the results of the analysis of published and archival documents of the Communist International and the Tuvan Peopless Revolutionary Party, ideological literature of the period of the Tuvan Peopless Republic to identify the features of the political socialization of Tuvan women. The author exposes the political influence of the Communist International on the Tuvan People's Republic, as well as the place of the women's issue in the domestic political agenda of Tuva, ideology and forms of work with women.
\end{abstract}

Keywords: Tuvan Peopless Republic, Tuvan women, political socialization, socio-political activity of women, government bodies 